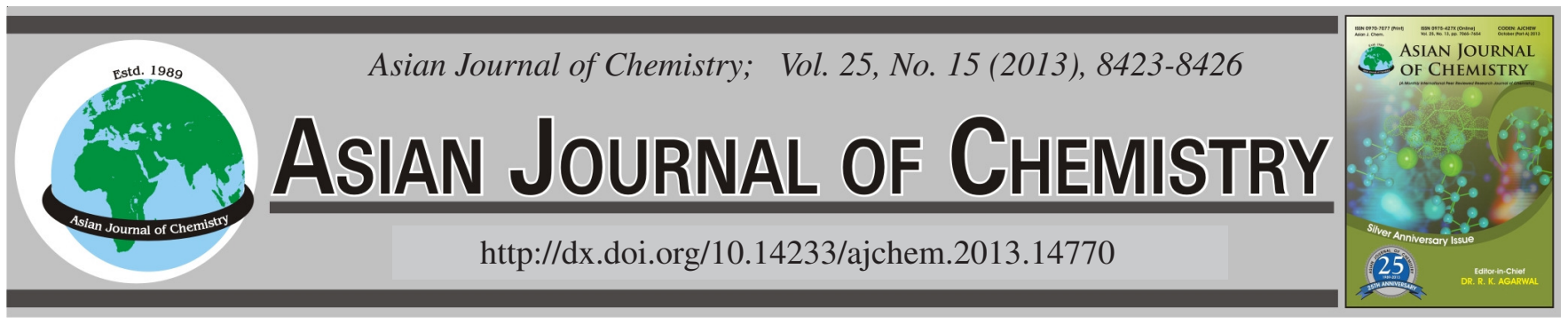

\title{
Vertical Distribution of Heavy Metal in Soil of Abandoned Vehicles Dismantling Area
}

\author{
Yanyu Wu*, Xiaochun Peng and Xiaoying Hu
}

South China Institute of Environmental Science, Ministry of Environmental Protection, Guangzhou 510655, P.R. China

*Corresponding author: Fax: +86 20 85557690; Tel: +86 20 85541902; E-mail: wuyanyu.scut@163.com; wuyanyu@scies.org

\begin{abstract}
In order to study heavy metal contamination in the soil of the abandoned vehicles dismantling area, the soil samples with vertical depth 0-1000 $\mathrm{cm}$ were collected and the physical and chemical characterizations of heavy metals e.g., $\mathrm{Cu}, \mathrm{Zn}, \mathrm{Pb}, \mathrm{Cr}, \mathrm{Ni}, \mathrm{Cd}, \mathrm{Hg}$ and $\mathrm{As}$ were analyzed. The correlation matrix was applied to evaluate the heavy metal contamination degree of soil samples. Moreover, the fractions of $\mathrm{Pb}$ and $\mathrm{Zn}$ in soils of various vertical depths were investigated. The results indicated that a certain degree of pollution had been caused in the superficial soil by heavy metals $\mathrm{Cu}, \mathrm{Zn}, \mathrm{Pb}, \mathrm{Cr}, \mathrm{Ni}, \mathrm{Cd}, \mathrm{Hg}$ and $\mathrm{As}$, where the contamination levels of $\mathrm{Pb}, \mathrm{Zn}, \mathrm{Cu}$ excessed significantly. A combined pollution characterization of $\mathrm{Cu}, \mathrm{Zn}, \mathrm{Pb}, \mathrm{Cr}, \mathrm{Ni}, \mathrm{Hg}$ and As was also presented. In addition, the concentrations of heavy metals in soils samples decreased exponentially with increasing the vertical depth, whereas the accumulated sub-standard depth of heavy metals $\mathrm{Pb}$ and $\mathrm{As}$ were still up to $150 \mathrm{~cm}$. The content of exchangeable ion state of $\mathrm{Pb}$ was lowest. The $\mathrm{pH}$ control functions in species of $\mathrm{Pb}$ of soil were not significant. With the soil of vertical depth increasing, the ratios of oxidizable $\mathrm{Pb}$ and light acidic soluble $\mathrm{Pb}$ reduced rapidly and the residual $\mathrm{Pb}$ increased gradually. The exchangeable ion state $\mathrm{Zn}$ and weak acid soluble $\mathrm{Zn}$ significantly correlated with the soil $\mathrm{pH}$ values. The main fraction of $\mathrm{Zn}$ in light acidic soil was exchangeable ion state and the main fractions of $\mathrm{Zn}$ in neutral soil were reducible and oxidizable fractions.
\end{abstract}

Key Words: Abandoned vehicle dismantling area, Heavy metal contamination, Vertical distribution, Lead, Zinc.

\section{INTRODUCTION}

Numbers of abandoned vehicles in China have grown rapidly over the past 10 years. In 2011, over 4,000,000 vehicles were reported abandoned. Moreover, an estimated figure of $14,000,000$ abandoned vehicles for the year 2020. As a result, the environmental problems associated with abandoned vehicles are becoming more acute. As the research reported ${ }^{1-4}$, one waste accumulator with average $20 \mathrm{~kg}$ lead and $10 \mathrm{~kg}$ waste acid, $10 \mathrm{~kg}$ waste oil can be obtained after decomposing one discarded vehicle. Environmental impact investigations carried out on the end-of-life vehicle reveal that the heavy metals $\mathrm{Pb}, \mathrm{Cd}, \mathrm{Zn}$ and $\mathrm{Cu}$, as well as waste oil, brake liquid and lubricants were the main contaminants. The spilling of vehicle fluids and the production of iron cuttings and machined pieces occurred during the mechanical processes such as pressing, grinding and separation into fractions of scrap iron. These inorganic heavy metals and organic oils penetrating into the soil result in the progressive soil contaminants, especially dismantled in the open without waterproof and protected against seepage and leaking ${ }^{2,3}$.
The aim of this work is to evaluate the vertical variations in the contents of several metallic elements involved in the soil of discarded vehicles area with various vertical depth. Soil samples with vertical depth $0-1000 \mathrm{~cm}$ were collected and the physical and chemical characterizations of $\mathrm{Cu}, \mathrm{Zn}, \mathrm{Pb}, \mathrm{Cr}, \mathrm{Ni}$, $\mathrm{Cd}, \mathrm{Hg}$ and $\mathrm{As}$ were analyzed. The contaminant impact of these metals will be evaluated by determination of the total and various extractable contents, taking into account the characteristics of these soils.

\section{EXPERIMENTAL}

Site description: The area of study is located in the vehicle dismantling area, in the industrial zone of South China (Guangzhou, China). The prevailing climate is subtropical monsoon climate of coast of South China with high temperature and rain. The yearly precipitation is $1200-2000 \mathrm{~mm}$. The main soil in the area is red clay with high water content.

Soil sampling and preparation: Soil samples were taken at depth intervals of $50 \mathrm{~cm}$ in the site situated to the dismantling area center. Abundant calcareous rock was present at a depth 
of $10 \mathrm{~cm}$, which indicates the low degree of differentiation of the soil profile, according to the poor weathering conditions.

The samples were collected in self-locking polythene bags and were sealed in double bags. Use of metal tools was avoided and a plastic spatula was used for sample collection. The samples were air-dried before analysis. The dry soil sample was finely powdered by swing-grinding mill and then sieved to 100 mesh size (US standard). The $\mathrm{pH}$ was measured on a sample of 1:25 soil to deionized water on volume basis.

Metal fractionation: Chemical fractions of $\mathrm{Pb}$ and $\mathrm{Zn}$ in the soil were obtained by a slight modification of the method of the sequential chemical extraction scheme described by Tessier et al. ${ }^{5}$. The BCR sequential extraction procedure proposed by European Union standard bureau in $1992^{6-8}$. The experiment conditions for five extraction procedures was shown in Table-1.

TABLE-1

\begin{tabular}{cccc}
\multicolumn{4}{c}{ EXPERIMENT CONDITIONS FOR EXTRACTION PROCEDURE } \\
\hline Fraction & Extraction solution & $\begin{array}{c}\text { Temp. } \\
\left({ }^{\circ} \mathrm{C}\right)\end{array}$ & $\begin{array}{c}\text { Time } \\
(\mathrm{h})\end{array}$ \\
\hline $\begin{array}{c}\text { Exchangeable } \\
\text { cations }\end{array}$ & $1 \mathrm{M} \mathrm{MgCl}_{2}(\mathrm{pH} 6)$ & 25 & 1 \\
Light acidic soluble & $0.1 \mathrm{M} \mathrm{AcOH}(\mathrm{pH} 4.9)$ & 25 & 1 \\
Reducible & $0.5 \mathrm{M} \mathrm{NH}_{2} \mathrm{OH} \cdot \mathrm{HCl}(\mathrm{pH} 2.2)$ & 60 & 1 \\
Oxidizable & $30 \%(\mathrm{~V} / \mathrm{V}) \mathrm{H}_{2} \mathrm{O}_{2}+1 \mathrm{M}$ & 85 & 1 \\
& $\mathrm{NH}_{4} \mathrm{OAc}(\mathrm{pH} 2-3)$ & & \\
Residue & $\mathrm{HNO}_{3}+\mathrm{H}_{2} \mathrm{O}_{2}+\mathrm{HF}$ & 190 & 2 \\
\hline
\end{tabular}

All glassware had been pre-cleaned and acid-washed before use. All reagents were of analytical grade and were used without further purification. Analysis blanks and duplicates were applied regularly. The experiments were done in duplicate. The results are based on triplicate analysis and the standard deviation is less than $5 \%$.

\section{RESULTS AND DISCUSSION}

Heavy metal contents of surface soils: The soil samples were analyzed according to the soil environmental background values of surface soil $(0-20 \mathrm{~cm})$ in Guangdong province, China ${ }^{9}$ (Table-2). Soil samples showed, remarkably higher contents of $\mathrm{Cu}, \mathrm{Zn}, \mathrm{Pb}, \mathrm{Cr}, \mathrm{Ni}, \mathrm{Cd}, \mathrm{Hg}$ and As compared with the soil environmental background values in Guangdong province indicated the activities of dismantling vehicles affected the heavy metals contents of surficial soil remarkably. In addition, the average contents of $\mathrm{Cu}, \mathrm{Zn} \mathrm{Hg}$ and $\mathrm{Pb}$ in surface soil samples were $258,828,0.80$ and $568 \mathrm{mg} / \mathrm{kg}$, which were 17.9 , 17.00, 10.6 and 16.5 times higher than the soil environmental background values in Guangdong province. The results accorded with the main pollution factors in abandoned vehicles dismantling area reported by Chicharro Martýìn et al. ${ }^{10}$. The contents of $\mathrm{Ni}, \mathrm{Cr}$, As and $\mathrm{Cd}$ were also 4.6, 4.2, 5.9 and 7.2 times higher than the background values, though their relative concentration were not much higher. It demonstrated the soil was also polluted by $\mathrm{Ni}, \mathrm{Cr}$, As and $\mathrm{Cd}$ from the waste autoparts and wastewater. This increase contamination may indicate possible mechanical infiltration and deposition of the contaminants originating from waste auto-parts, as well as scrap iron cutting, pressing and storing activities.

Heavy metal contents at various soil depth intervals: The heavy metals contents and $\mathrm{pH}$ values of soil samples with various depth were shown in Fig. 1. The heavy metal contents declined exponentially with increasing soil depth indicate possible adsorption and deposition of the contaminants particles on the soil ${ }^{11,12}$. This distribution characteristic has already been confirmed that the precipitation infiltration largely influenced on the heavy metal contaminants activities ${ }^{13}$. The concentrations of $114.69 \mathrm{mg} / \mathrm{kg}$ for $\mathrm{Pb}, 153.17 \mathrm{mg} / \mathrm{kg}$ for $\mathrm{Zn}$, $55.88 \mathrm{mg} / \mathrm{kg}$ for $\mathrm{Cr}$ and $52.49 \mathrm{mg} / \mathrm{kg}$ for As in the soil samples with $150 \mathrm{~cm}$ depth were still remarkable, indicating vertical dispersion of contamination in soils. The metals speciation, leaching, soil physico-chemical properties influenced on heavy metals transportations, but the migration depth was limited and not over $200 \mathrm{~cm}$. The Cd content in surface soil was higher than the soil environmental background values in Guangdong province. whereas The presence of $\mathrm{Cd}$ in surfacial soil was much lower than the environmental quality standard for soils of China (GB 15618-2008) ${ }^{14}$.
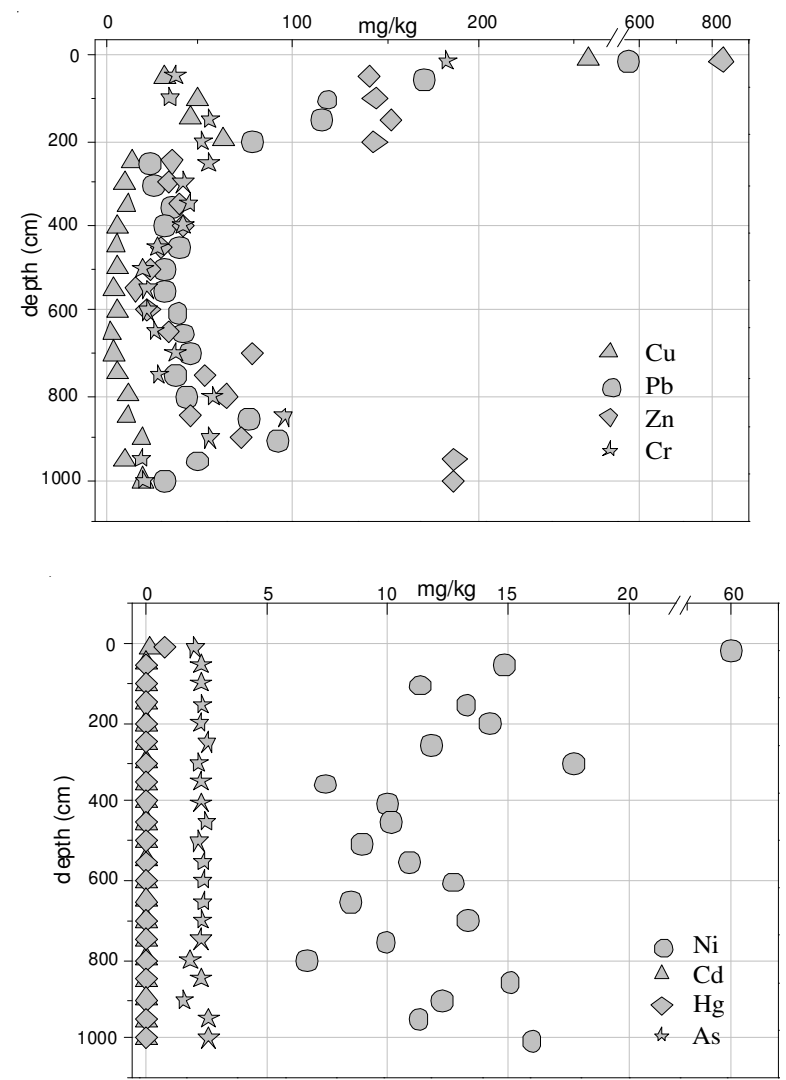

Fig. 1. Heavy metals of the soil samples in the discarded vehicles range with depth

TABLE-2

ANALYSIS OF SURFACE SOIL IN THE DISCARDED VEHICLES RANGE

\begin{tabular}{|c|c|c|c|c|c|c|c|c|}
\hline Average content (mg/kg) & $\mathrm{Cu}$ & $\mathrm{Ni}$ & $\mathrm{Pb}$ & $\mathrm{Cd}$ & $\mathrm{Cr}$ & $\mathrm{Zn}$ & $\mathrm{Hg}$ & As \\
\hline Surface so & 257.85 & 59.82 & 568.12 & 0.240 & 182.17 & 827.84 & 0.800 & 62.08 \\
\hline Environmental background values in Guangdong province & 14.38 & 13.00 & 34.38 & 0.034 & 43.25 & 48.75 & 0.075 & 10.50 \\
\hline
\end{tabular}


Pollution characteristics: The heavy metals contamination of soils were assessed based on the single factor contaminant index with the environmental quality standard for soils in China (GB 15618-2008) ${ }^{14}$. In this paper, data were statistically analyzed by ANOVA test using a statistical package, SPSS version 18.0. The contaminant index of soil in dismantling area contaminated by heavy metals were shown in Fig. 2 the results indicated that except $\mathrm{Ni}$ and $\mathrm{Cr}$, other heavy metal contents were more than secondary national standards of China. It was typical heavy metal pollution in soils in the dismantling area, especially the metal $\mathrm{Pb}, \mathrm{Zn}$ and $\mathrm{Cu}$ pollution. A tendency of a progressive decrease with depth from the dismantling site seem to verify a common origin of the metallic contamination of these soils, which is due to the dismantling activities of lead-accumulator, as well as other waste autoparts contained $\mathrm{Pb}, \mathrm{Zn}$ and $\mathrm{Cu}$ etc. while the soil depth higher over $50 \mathrm{~cm}$, the $\mathrm{Pb}$ and $\mathrm{As}$ contaminant index were still higher 1.0, whereas other heavy metals index all lower 0.47. All index decreased lower than 0.47 while the soil depth over 200 $\mathrm{cm}$, demonstrating the heavy pollution was indistinctive with the soil depth over $150 \mathrm{~cm}$. It was noted that the $\mathrm{Cr}$ and $\mathrm{Ni}$ pollution had not not obviously effected on the dismantling area soil.

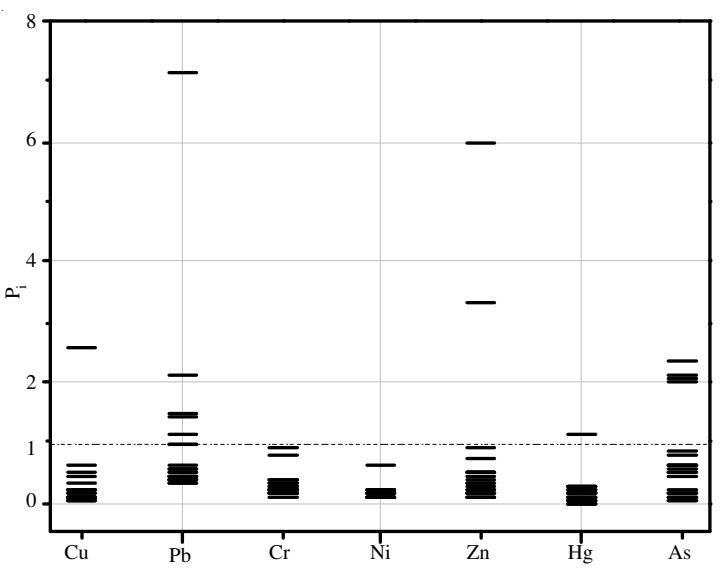

Fig. 2. Pollution index of heavy metals in soil

Significant correlation analysis of multi-metal contaminated soil: The partial correlation coefficients and significant levels between various metals were shown in Table-3 with $\mathrm{pH}$ and variable soil depth. It was noted that the highly significant correlation among the contents of the $\mathrm{Cu}, \mathrm{Zn}, \mathrm{Pb}, \mathrm{Cr}, \mathrm{Ni}$, $\mathrm{Cd}, \mathrm{Hg}$ and As determined seemed to verify a common origin of the metallic contamination of these soils, which is due to the dismantling activities of abandoned bus, truck and motorbike. The metals $\mathrm{Pb}, \mathrm{Zn}, \mathrm{Cu}, \mathrm{Hg}$ and As containing in waste battery and discarded lamps of vehicle influenced the soil heavily.

Species of $\mathbf{P b}$ and $\mathbf{Z n}$ : The characteristics of species $\mathrm{Pb}$ and $\mathrm{Zn}$ in soil with various depth intervals were illustrated in Fig. 3. The percentage of exchangeable species $\mathrm{Pb}$ changed insignificantly with the increase of soil depth and the deduction of total $\mathrm{Pb}$ content, whereas the contents of oxidizable and light acidic soluble species $\mathrm{Pb}$ decreased sharply. At the same time, the residue species $\mathrm{Pb}$ improved gradually. The presence of organic compounds in soil decreased with the depth may

\begin{tabular}{cccccccc}
\multicolumn{7}{c}{ TABLE-3 } \\
\multicolumn{7}{c}{ CRRELATION COEFFICIENT OF HEAVY } \\
METALS WITH THE SOIL DEPTH
\end{tabular}
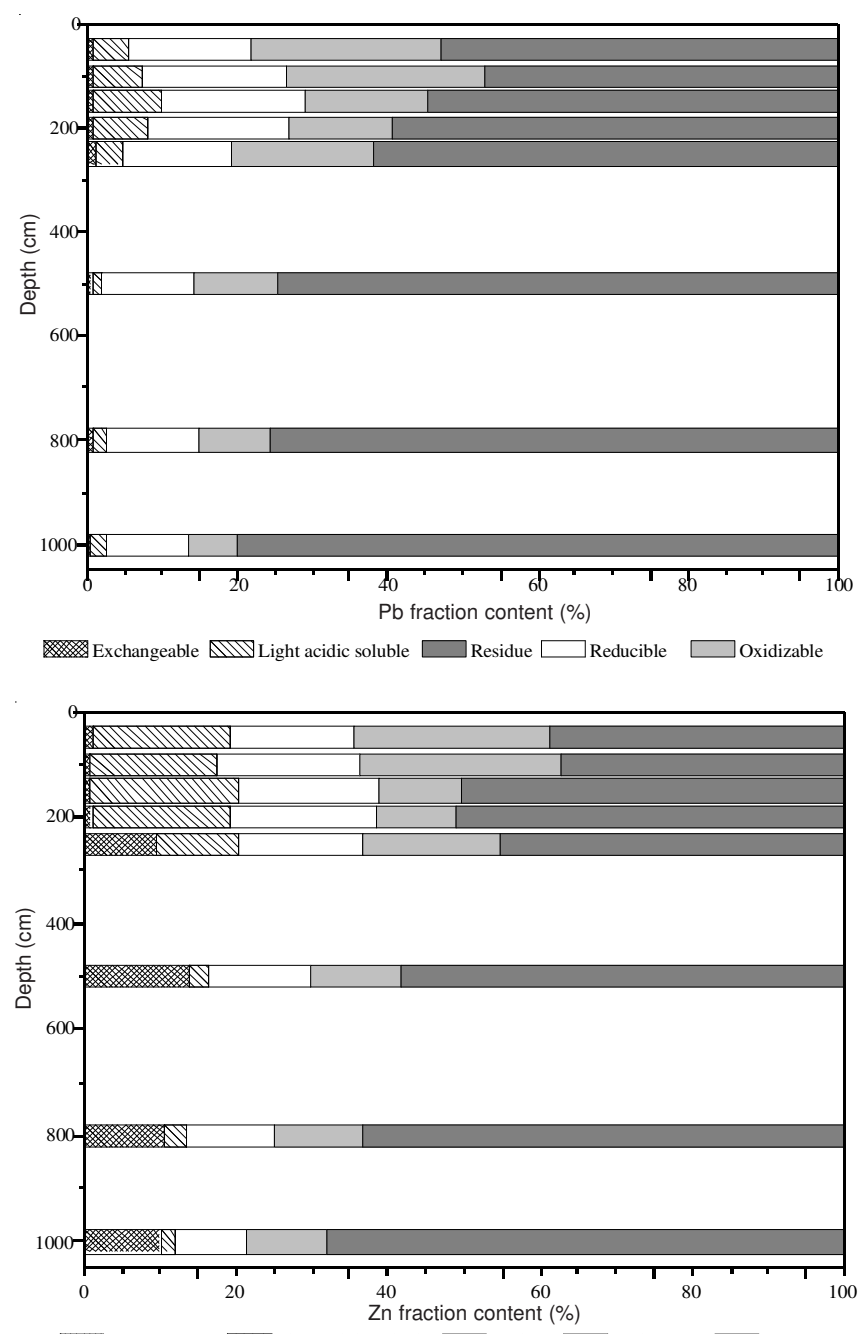

Exchangeable $\mathbb{M}$ Light acidic soluble $\square$ Residue $\square$ Reducible $\square$ Oxidizable

Fig. 3. Relative concentrations of $\mathrm{Pb}$ species with the depth of soil samples

have direct and indirect effects on heavy metal mobility and reactivity. Moreover, the light acidic soil result in the decrease of the content of light acidic species $\mathrm{Pb}$ when the soil depth increased, because the formation of $\mathrm{PbCO}_{3}$ in light acidic $\mathrm{pH}$ reduce the deposition of the products of $\mathrm{Pb}_{3}\left(\mathrm{CO}_{3}\right)_{2} \mathrm{OH}_{2}$ and result in an decrease of soil desorption ${ }^{15-17}$.

As shown in Fig. 3, a generalized enrichment of the superficial level $(0-20 \mathrm{~cm})$ and a gradual decrease with depth were observed for the target element $\mathrm{Zn}$. Light acidic soluble $\mathrm{Zn}$ was the main species in basic $\mathrm{pH}$ soil, probably as a consequence of the formation of $\mathrm{ZnCO}_{3} \mathrm{Zn}_{5}\left(\mathrm{CO}_{3}\right)_{2}(\mathrm{OH})_{6}$ deposition in basic soil with much free carbonate ${ }^{18-20}$. Moreover, the extractable contents of $\mathrm{Zn}$ were the main fraction in light acidic 
TABLE-4

CORRELATION ANALYSIS OF HEAVY METALS WITH VARIOUS SPECIES AND DEPTH

\begin{tabular}{|c|c|c|c|c|c|c|c|c|c|}
\hline & & Depth & $\mathrm{pH}$ & Exchangeable cations & Light acidic soluble & Reducible & Oxidizable & Residue & \\
\hline \multirow{6}{*}{$\mathrm{Pb}$} & $\mathrm{pH}$ & -0.553 & 1 & $-0.942^{* *}$ & $0.872^{* *}$ & 0.549 & 0.250 & -0.451 & \multirow{6}{*}{$\mathrm{Zn}$} \\
\hline & Exchangeable cations & -0.566 & 0.033 & 1 & $-0.929^{* *}$ & -0.546 & -0.303 & 0.490 & \\
\hline & Light acidic soluble & -0.588 & 0.344 & $0.862^{* *}$ & 1 & $0.755^{*}$ & 0.394 & $-0.686^{*}$ & \\
\hline & Reducible & $-0.841^{* *}$ & 0.620 & $0.704^{*}$ & $0.885^{* *}$ & 1 & 0.544 & $-0.875^{* *}$ & \\
\hline & Oxidizable & $-0.838^{* *}$ & 0.514 & 0.367 & 0.308 & 0.582 & 1 & $-0.867^{* *}$ & \\
\hline & Residue & $0.887^{* *}$ & -0.556 & $-0.768^{*}$ & $-0.846^{* *}$ & $-0.947^{* *}$ & $-0.762^{*}$ & 1 & \\
\hline
\end{tabular}

$\mathrm{pH}$ soil and the reducible and oxidizable contents of $\mathrm{Zn}$ were the main fraction in neutral soil. A. Chicharro Martýìn et al. ${ }^{10}$ and Barrow $^{21}$ also indicated that the formation of insoluble precipitates of heavy metal oxides and hydroxides was likely to take place under various edaphic conditions with different $\mathrm{pH}$ and organic content.

Table-4 illustrates the correlation analysis results of $\mathrm{Pb}$ and $\mathrm{Zn}$ with various fractions. The left bottom and right bottom present the data of $\mathrm{Pb}$ and $\mathrm{Zn}$, respectively. No significant correlation among $\mathrm{pH}$ value and various contents of $\mathrm{Pb}$ species in the soils had been observed. The observation indicated that the $\mathrm{pH}$ value of soil had not remarkable influence on $\mathrm{Pb}$ conents with various species. However, $\mathrm{pH}$ values significantly influent the exchangeable and light acidic soluble $\mathrm{Zn}$ species in soil.

\section{Conclusion}

There was a certain degree of pollution had been caused in the superficial soil by heavy metals $\mathrm{Cu}, \mathrm{Zn}, \mathrm{Pb}, \mathrm{Cr}, \mathrm{Ni}, \mathrm{Cd}$, $\mathrm{Hg}$ and $\mathrm{As}$, where the contamination levels of $\mathrm{Pb}, \mathrm{Zn}, \mathrm{Cu}$ excessed significantly. There was vertical dispersion of contamination in soils with $150 \mathrm{~cm}$ depth interval, but not over 200 $\mathrm{cm}$. The contaminants in soil with multi-metals pollution characteristic mainly originate from the dismantling activities of discarded vehicles containing $\mathrm{Cu}, \mathrm{Ni}, \mathrm{Pb}, \mathrm{Cr}, \mathrm{Zn}, \mathrm{Hg}$ and As in auto-parts such as waste battery and lamps.

The presence of organic compounds in soil decreased with the depth may have direct and indirect effects on heavy metal mobility and reactivity. The percentage of exchangeable species $\mathrm{Pb}$ changed insignificantly with the increase of soil depth and the deduction of total $\mathrm{Pb}$ content, whereas the contents of oxidizable and light acidic soluble species $\mathrm{Pb}$ decreased sharply. At the same time, the residue species $\mathrm{Pb}$ improved gradually. Light acidic soluble $\mathrm{Zn}$ was the main species in basic $\mathrm{pH}$ soil, the extractable contents of $\mathrm{Zn}$ were the main fraction in light acidic $\mathrm{pH}$ soil and the reducible and oxidizable fractions of $\mathrm{Zn}$ were the main contents in neutral soil.

\section{ACKNOWLEDGEMENTS}

The authors gratefully acknowledged the financial support from the National Environment Protection Program for Commonweal Industry of China (No. 201009063, 2011467024, 201209022, No. ZX-200809-06 and ZX-201106-089) and also like to acknowledged the full assistance from staffs for this study.

\section{REFERENCES}

1. F. Mathieux and D. Brissaud, Resour. Conserv. Recycl., 55, 92 (2010).

2. A. Santini, L. Morselli, F. Passarini, I. Vassura, S. Di Carlo and F. Bonino, Waste Manage., 31, 489 (2011).

3. S. Bhatnagar and R. Kumari, Ann. Rev. Res. Biol., 3, 974 (2013).

4. O. P. Abioye, P. Agamuthu and A.R. Abdul Aziz, Biotechnol. Res. Int., Article ID 587041 (2012)

5. A. Tessier, P.G.C.C. and M. Bisson, Anal. Chem., 51, 844 (1979).

6. S. Tokalioglu, V. Yilmaz and S. Kartal, Clean-Soil Air Water, 38, 713 (2010).

7. M. Zemberyová, J. Barteková and I. Hagarová, Talanta, 70, 973 (2006).

8. E. Doelsch, G. Moussard and H.S. Macary, Geoderma, 143, 168 (2008).

9. CNEMC, The Background Contents of Elements in Chinese Soil, Beijing, CSEP, (1990) in Chinese.

10. A.C. Martìn, V.C. Rivero and M.T. Larrea Marìn, Sci. Total Environ., 212, 145 (1998).

11. U. Blaha, E. Appel and H. Stanjek, Environ. Pollut., 156, 278 (2008).

12. J. Molas and S. Baran, Geoderma, 122, 247 (2004).

13. M.A. Hossain, H. Furumai, F. Nakajima and R.K. Aryal, Water Sci. Technol., 56, 81 (2007).

14. Soil Environmental Quality Standard GB 15618-200, Beijing (2008) (in Chinese).

15. C. de la Fuente, R. Clemente and M.P. Bernal, Ecotoxicol. Environ. Saf., 70, 207 (2008).

16. W. Geebelen, D.C. Adriano, D. van der Lelie, M. Mench, R. Carleer, H. Clijsters and J. Vangronsveld, Plant Soil, 249, 217 (2003).

17. S. Khan, D. Nandan and N.N. Khan, Environ. Pollut. B, 4, 119 (1982).

18. J. Komisarek and K. Wiatrowska, Pollut. J. Environ. Stud., 18, 1029 (2009).

19. A.R.A. Usman and A. Ghallab, Chem. Ecol., 22, 267 (2006).

20. A. Voegelin, K. Barmettler and R. Kretzschmar, J. Environ. Qual., 32, 865 (2003).

21. N.J. Barrow, In ed.: N.C. Brady, Reaction of Anions and Cations with Variable-Charge Soils in Advance Agronomy, Academic Press, p. 183 (1986). 